\title{
圧延ワークロールの 表層亀裂における応力拡大係数の数値解析
}

山本 普康*・内田 秀*・橋本 光生*2

Numerical Analysis of Stress Intensity Factors of Crack in Subsurface Layer of Work Roll for Rolling Hiroyasu Yамамото, Shigeru Uсhida and Mitsuo НаSнimoto

Synopsis : A simplified model for stress intensity factors of mixed modes was derived in consideration of non-dimensional stress intensity factors obtained by Murakami et al. A numerical analysis model for stress intensity factors of mixed modes in the subsurface layer of work roll of rolling was also obtained by applying this simplified model to the deformation analysis model for the thermal elastic-plastic stress and strain in the subsurface layer of work roll with stress and thermal loads. Then, the stress intensity factors in the subsurface layer of work roll in hot rolling were calculated with this numerical analysis model. It has been found that the stress intensity factors of tensile and shear modes on the side of intermediate roll is larger than those on the side of rolling material and that the crack propagation is estimated to occur on the side of intermediate roll, etc.

Key words : crack ; crack propagation ; stress intensity factor ; rolling ; work roll ; subsurface layer ; hot rolling ; numerical analysis.

\section{1. 緒言}

熱間圧延では，WR(ワークロール)は応力負荷と熱負荷 老繰り返し受け，WR表層部に熱亀裂等の欠陥が発生する。 このような初期亀裂が存在する状態で過大な応力が繰り返 し負荷されると，初期亀裂を起点にして剪断型モードの龟 裂が伝播する ${ }^{1)}$ 。亀裂の伝播に関する数值解析は, 一般に単 純モードの応力拡大係数 2 を用いて行われている3-5)。(か し, WR表層部では 3 軸方向の応力が存在するため, 複合 モードの応力拡大係数6を用いる必要がある。このような 複合モードの応力拡大係数を用いた 2 月筒接触の数值解析 例は少なく7), 特に熱間圧延のように, 熱負荷が作用する条 件での数值解析例は見あたらない。

本報告では，村上 ( $^{5)}$ が求めた無次元応力拡大係数の簡 易式を考虑して，複合モードの応力拡大係数の簡易モデル を導出する。そして，既に報告している压延ロール表層の 応力・熱負荷連成の熱弾塑性応力・歪数值解析モデル8)にこ の簡易モデルを適用して，冷間・熱間圧延WRの表層亀裂に おける応力拡大係数の簡易数值解析モデルを作成する。ま た，冷間 2 円筒接触の計算において，今回導いた簡易数值

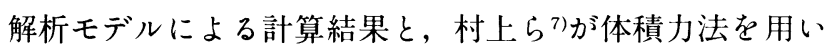
て作成した複合モードの応力拡大係数の数值解析モデルに よる計算結果とを比較する。さらに, 熱間圧延におけるWR の表層亀裂の応力拡大係数に及ぼす荷重負荷の位置や亀裂
角度等の影響を解明し，表層亀裂の伝播機構を考察する。

\section{2. 複合モードの応力拡大係数の簡易モデル}

$$
\text { モードI とモードIIが混在する複合モードの場合には, }
$$

Fig. 1 に示寸亀裂の先端Pにおける引張型応力拡大係数 $\mathrm{K} \sigma$ と剪断型応力拡大係数 $\mathrm{K} \tau$ は，以下のように表される6)。

$$
\mathrm{K}_{\sigma}=\cos \frac{\theta}{2}\left[\mathrm{~K}_{\mathrm{I}} \cos ^{2} \frac{\theta}{2}-\frac{3}{2} \mathrm{~K}_{\mathrm{II}} \sin \theta\right]
$$

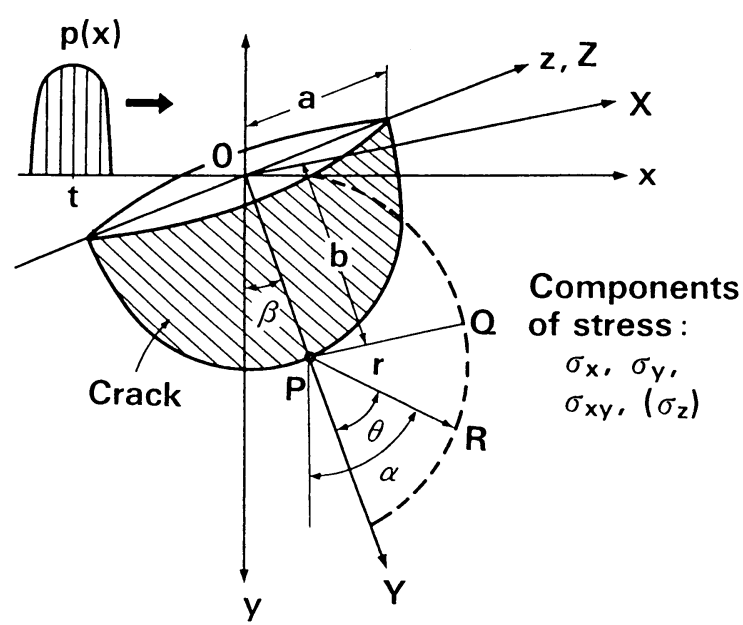

Fig. 1. Crack model in subsurface layer of work $\operatorname{roll}(Z, z:$ axis of work roll. $\beta, \theta$ and $\alpha$ show negative values in the figure).

平成 8 年12月13日受付 平成 9 年 4 月11日受理（Received on Dec. 13, 1996; Accepted on Apr. 11, 1997）

* 新日本製鐵(株) プロセス技術研究所 (Process Technology Research Laboratories, Nippon Steel Corp., 20-1 Shintomi Futtsu 293)

* 2 新日本製鐵(株) 機械プラント事業部（Plant and Mechinery Division, Nippon Steel Corp.) 


$$
\mathrm{K}_{\tau}=\frac{1}{2} \cos \frac{\theta}{2}\left[\mathrm{~K}_{\mathrm{I}} \sin \theta+\mathrm{K}_{\mathrm{II}}(3 \cos \theta-1)\right]
$$

ここで, $\mathrm{K}_{\mathrm{I}}$ と $\mathrm{K}_{\mathrm{II}}$ はモード I とモード II の応力拡大係数で あり, $\theta$ は亀裂先端Pを中心としたX, Y座標上のY軸からの 角度である。

今, Fig.1に示したように, 亀裂を半楕円とし，その軸長 をаおよびbとすると，亀裂先端PにおけるモードI とモー ドIIの応力拡大係数 $\mathrm{K}_{\mathrm{I}}$ および $\mathrm{K}_{\mathrm{II}}$ は, 村上 $5^{5)}$ が求めた無次 元応力拡大係数の簡易式 $\mathrm{f}_{\mathrm{I}}$ と $\mathrm{f}_{\mathrm{II}}$ を用いることによって, 以 下のように与えられる。

$$
\left.\begin{array}{rl}
\mathrm{K}_{\mathrm{I}} & =\mathrm{f}_{\mathrm{I}} \sigma_{\mathrm{x}} \sqrt{\pi \mathrm{b}} \\
\mathrm{f}_{\mathrm{I}} & =0.660+0.23 \beta^{2}+\left(0.462+0.17 \beta^{2}\right)\left(1-\frac{\mathrm{b}}{\mathrm{a}}\right)
\end{array}\right\}
$$

$$
\begin{aligned}
\mathrm{K}_{\mathrm{II}} & =-\mathrm{f}_{\mathrm{II}} \sigma_{\mathrm{XY}} \sqrt{\pi \mathrm{b}} \\
\mathrm{f}_{\mathrm{II}} & =0.71-0.13 \frac{\mathrm{b}}{\mathrm{a}}
\end{aligned}
$$

ここで, Fig.2 に示すように， $\sigma_{X} \varepsilon \sigma_{X Y}$ は亀裂先端近傍のX, Y座標系における応力成分であり， $\beta$ は，y座標上における 亀裂面 (Y軸が亀裂面上に存在) のy軸からの角度である。 今, $\mathrm{x}, \mathrm{y}$ 座標系における応力成分を $\sigma_{\mathrm{x}}, \sigma_{\mathrm{y}}, \sigma_{\mathrm{xy}}$ とすると, $\mathrm{X}, \mathrm{Y}$ 座標系における応分成分 $\sigma_{\mathrm{X}}$ と $\sigma_{\mathrm{XY}}$ は, Fig. 2 から以下の 式で与えられる。

$$
\begin{aligned}
& \sigma_{x}=\frac{\sigma_{x}+\sigma_{y}}{2}+\frac{\sigma_{x}-\sigma_{y}}{2} \cos 2 \beta+\sigma_{x y} \sin 2 \beta \\
& \sigma_{\mathrm{XY}}=-\frac{\sigma_{x}-\sigma_{y}}{2} \sin 2 \beta+\sigma_{x y} \cos 2 \beta \\
& \text { したがって，式（3）～式（６）を式（1）と式（２）に代入す }
\end{aligned}
$$

ると, Fig. 1 に示した亀裂先端Pにおける引張型応力拡大 係数 $\mathrm{K} \sigma$ と剪断型応力拡大係数 $\mathrm{K} \tau$ が求められる。なお, 応力 $\sigma_{\mathrm{x}}, \sigma_{\mathrm{y}}, \sigma_{\mathrm{xy}}$ は，既に報告している圧延ロール表層の応力・ 熱負荷連成の熱弾塑性応力・歪数值解析モデル ${ }^{8)}$ にって 求められる。今回, 応力 $\sigma_{x}, \sigma_{y}, \sigma_{x y} と し て は$, 龟裂先端 $P$

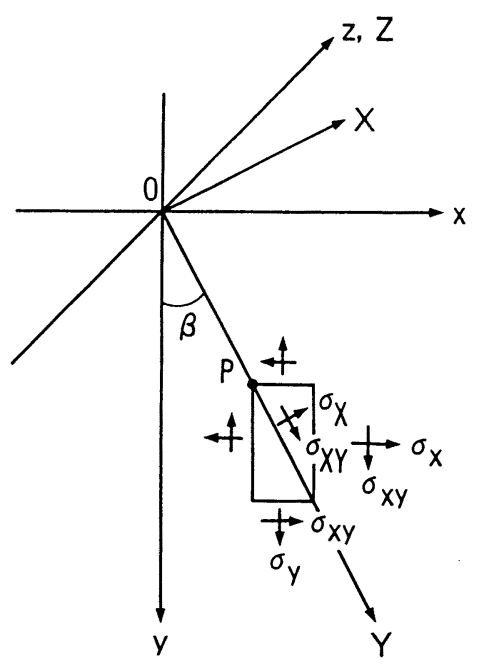

Fig. 2. $\mathrm{x}, \mathrm{y}$ and $\mathrm{X}, \mathrm{Y}$ coordinate $\operatorname{systems}(\beta$ is a negative value in the figure).
を中心にして幅 (x方向)が接触長 (Fig.1 に示した荷重分布 $\mathrm{p}(\mathrm{x})$ の $\mathrm{x}$ 軸上の幅)の 0.3 倍, 深さ (y方向)が接触長の 1.5 倍 の範囲における表層内の応力の平均値で与えた。なお，圧 延ロールのようなころがり・すべり問題においては, 荷重 分布位置が円周上を移動するため, 応力拡大係数の極大と 極小の位置は重要ではなく, 極大と極小の大きさが重要と なる。

そこで，この考え方に従って，これらの数值解析モデル によって求められる複合モードの応力拡大係数が, 村上

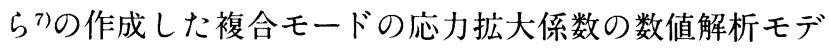
ルによって計算される值とできるだけ等しくなるように， 式 ( 3 ) と式 (4)の中の無次元応力拡大係数 $\mathrm{f}_{\mathrm{I}}$ と $\mathrm{f}_{\text {II }}$ を以下の ように修正した。

$$
\begin{aligned}
\mathrm{f}_{\mathrm{I}}= & 0.660+0.23 \beta^{2}+\left(0.462+0.17 \beta^{2}\right) \\
& \times\left[1-\frac{\mathrm{b}}{0.667(\mathrm{~b}-\mathrm{a})+\mathrm{a}}\right] \cdots \cdots \cdots \cdots \\
\mathrm{f}_{\text {II }}= & 0.71-0.13 \frac{\mathrm{b}}{0.667(\mathrm{~b}-\mathrm{a})+\mathrm{a}} \cdots \cdots \cdots
\end{aligned}
$$

\section{3. 数値解析モデルの比較}

今回導いた応力拡大係数の簡易数值解析モデルによる計 算結果と村上ら 7 の数值解析モデルによる計算結果とを比

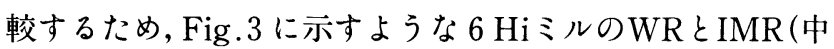
間ロール)との間 (B側)の接触荷重によって, WR表層に存 在する亀裂の先端の応力拡大係数を計算する。Fig.3の中 で, $\mathrm{t}$ は荷重分布の中心位置であり, $\ell_{\mathrm{A}}$ および $\ell_{\mathrm{B}}$ はWRの 接触弧長の $1 / 2$ である。Table 1 に計算条件を示す。村上ら 7 ) の数值解析モデルは温度の計算が含まれていないため, 冷 間の条件で計算を行う。ロール径はWRが がф $800 \mathrm{~mm}$ である。線荷重は $9.8 \mathrm{KN} / \mathrm{mm}$, WR と IMR と の間の摩擦係数 $\mu_{\mathrm{B}}$ は 0 と 0.2 である。ロールのヤング率 $\mathrm{E}$

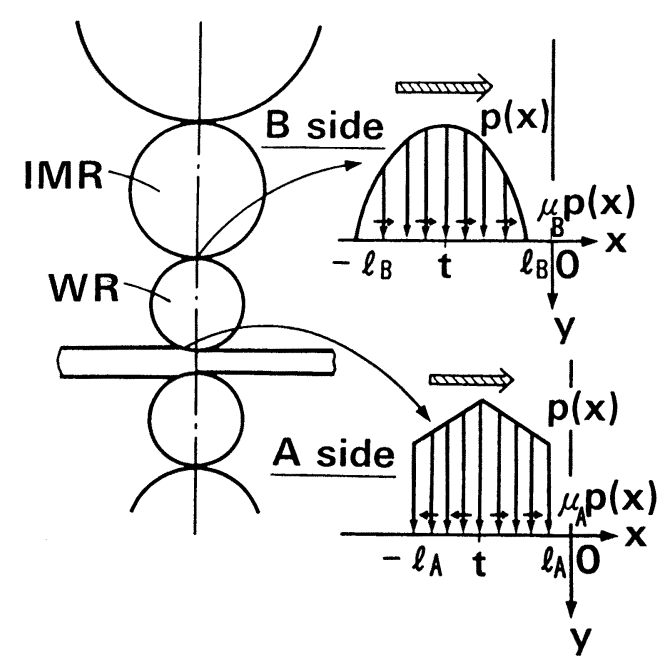

Fig. 3. Rolling model of $6 \mathrm{Hi}$ mill(A side : between WR and strip, $B$ side: between WR and IMR). 
は 206GPa，降伏応力は $1765 \mathrm{MPa}$ ，応力歪曲線の勾配はE/ 10である。WR表層の半棈円亀裂の寸法は, 幅 2 aが $2 \mathrm{~mm}$, 深さbが $1 \mathrm{~mm}$ であり，亀裂角度 $\beta$ は $0^{\circ}$ である。

Fig. 4 と Fig. 5 は, 摩擦係数 $\mu_{\mathrm{B}}$ が 0 と 0.2 の場合の今回の 数值解析モデルによる計算結果と村上らつの数值解析モデ ルによる計算結果との比較である。ここで, 横軸はFig. 3 の

Table 1. Calculation conditions for comparison of present and Murakami's models.

1. Roll diameter
WR: $\phi 600 \mathrm{~mm}$, IMR $: \phi 800 \mathrm{~mm}$
2. Rolling load per unit width
$p=9.8 \mathrm{kN} / \mathrm{mm}(1 \mathrm{tf} / \mathrm{mm})$
3. Friction coefficient between WR and IMR
$\mu_{B}=0,0.2$
4. Young's modulus of roll
$E=206 \mathrm{GPa}\left(21000 \mathrm{kgf} / \mathrm{mm}^{2}\right)$
5. Compression yield stress and hardening
modulus of roll
$\sigma y=1765 \mathrm{MPa} \quad\left(180 \mathrm{kgf} / \mathrm{mm}^{2}\right)$
$H=E / 10$
6. Initial residual stress : 0
7. Crack size (half ollipse)
Width: $2 a=2 \mathrm{~mm}, \quad$ Depth $: b=1 \mathrm{~mm}$
8. Crack angle: $\beta=0^{\circ}$

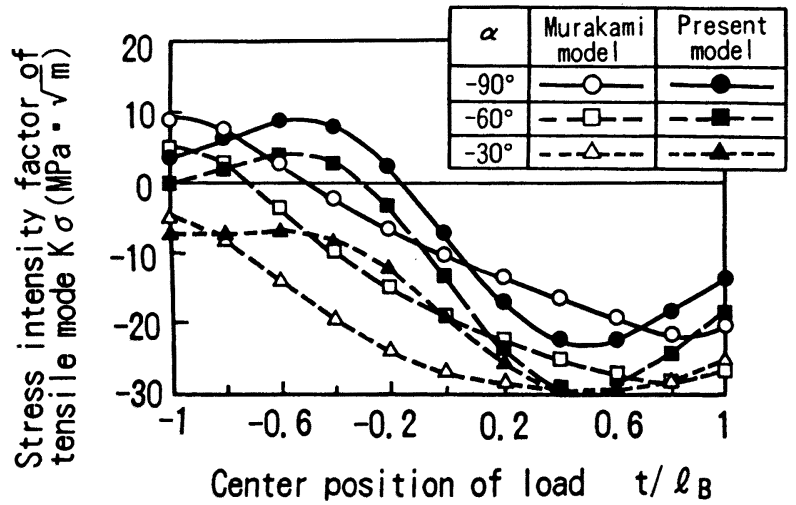

(a) Stress intensity factor of tensile mode $K \sigma$

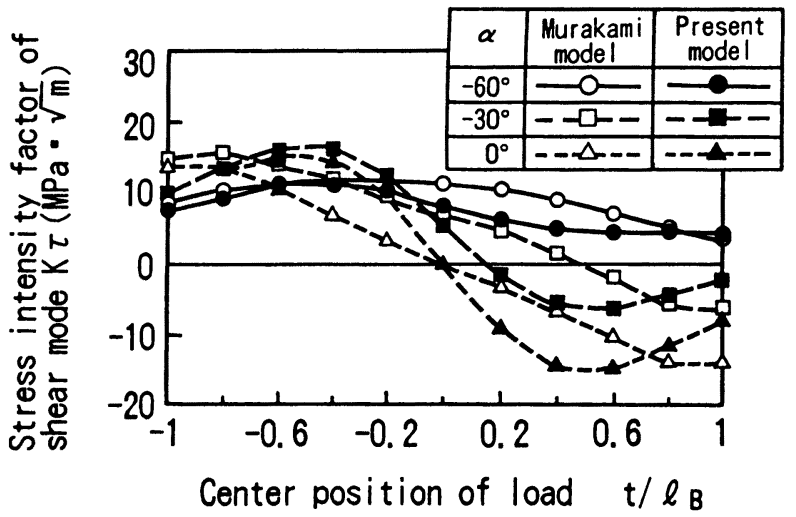

(b) Stress intensity factor of shear mode $K \tau$

Fig. 4. Comparison of present and Murakami's models with regard to stress intensity factors of tensile and shear modes $\left(\mu_{\mathrm{B}}=0, \beta=0^{\circ}\right.$, $\ell_{\mathrm{B}}=2.18 \mathrm{~mm}$ ). モデルのx軸上における荷重分布の中心七の位置を示し, 縦 軸の応力拡大係数の值はFig.3 のモデルの荷重分布の中心 がtの位置にある時の $\mathrm{x}=0$ における計算值を示す。摩擦係 数 $\mu_{\mathrm{B}}$ が 0 および 0.2 のいずれにおいても，引張型および剪 断型の応力拡大係数 $\mathrm{K}_{\sigma}$ および $\mathrm{K}_{\tau}$ の極大と極小を示す位置 は，今回のモデルと村上らうのモデルで若干異なっている が, 極大值および極小值に関しては, 両モデルははぼ同程 度の大きさを示す。

村上らフのモデルは, ロール表層の応力の計算に弾塑性 有限要素法を用い, 応力拡大係数の計算に体積力法を使用 した厳密な計算である。一方, 今回のモデルは, ロール表 層の応力の計算にMerwin $5^{99}$ の弹塑性変形数值解析法を 適用し，応力拡大係数の計算に村上 $5^{5)}$ の簡易式を使用し た簡易計算法である。Fig. 4 と Fig. 5 に示した両モデルの 差異は,このような計算方法の違いによって生じたもので ある。しかし, 圧延ロールのようなころがり・すべり問題 では, 荷重分布位置が円周上を移動するため, 応力拡大係 数の極大と極小の位置は重要ではなく, 極大と極小の大き さが重要となる。このことを考慮すると, 今回導いた応力 拡大係数の簡易数值解析モデルは, 压延ロールの表層亀裂 の解析に十分適用できると考えられる。

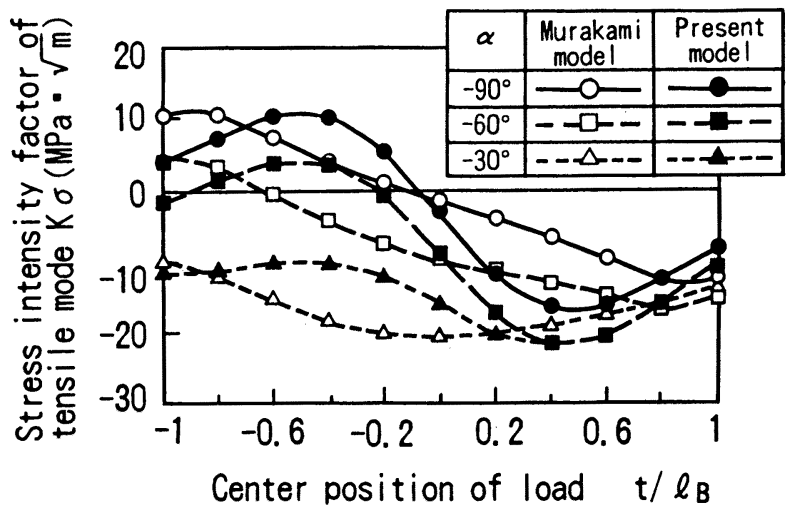

(a) Stress intensity factor of tensile mode $K \sigma$

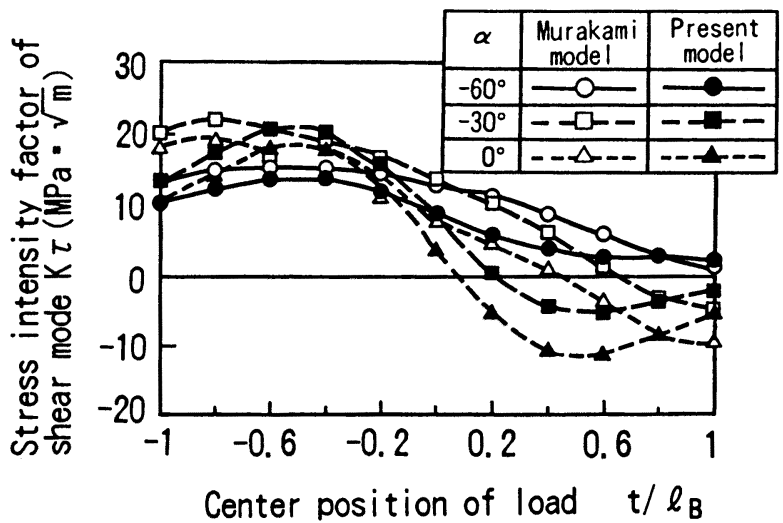

(b) Stress intensity factor of shear mode $K \tau$

Fig. 5. Comparison of present and Murakami's models with regard to stress intensity factors of tensile and shear modes $\left(\mu_{\mathrm{B}}=0.2, \beta=\right.$ $\left.0^{\circ}, \ell_{\mathrm{B}}=2.18 \mathrm{~mm}\right)$. 


\section{4. 熱延WR表層亀裂の応力拡大係数の数値解 析亡考察}

熱間圧延のWR表層の亀裂の伝播特性を明らかにするた め, 熱間圧延によって加熱冷却を受ける $6 \mathrm{Hi} ル ル の W R$ 表 層に存在する亀裂の先端の応力拡大係数を計算する。計算 条件には, Table 1 に示した条件の内, WRの圧縮降伏応力 と応力歪曲線の勾配とを除いた条件を使用し，それ以外の 条件としてはTable 2 に示すものを用いる。Fig.6 は，WR 材料の常温 $\left(25^{\circ} \mathrm{C}\right)$ における圧縮応力と歪の関係である。高 温におけるこの材料の圧縮応力と歪の関係式は, Fig.6 と

Table 2. Calculation conditions for stress intensity factors in subsurface layer of work roll.

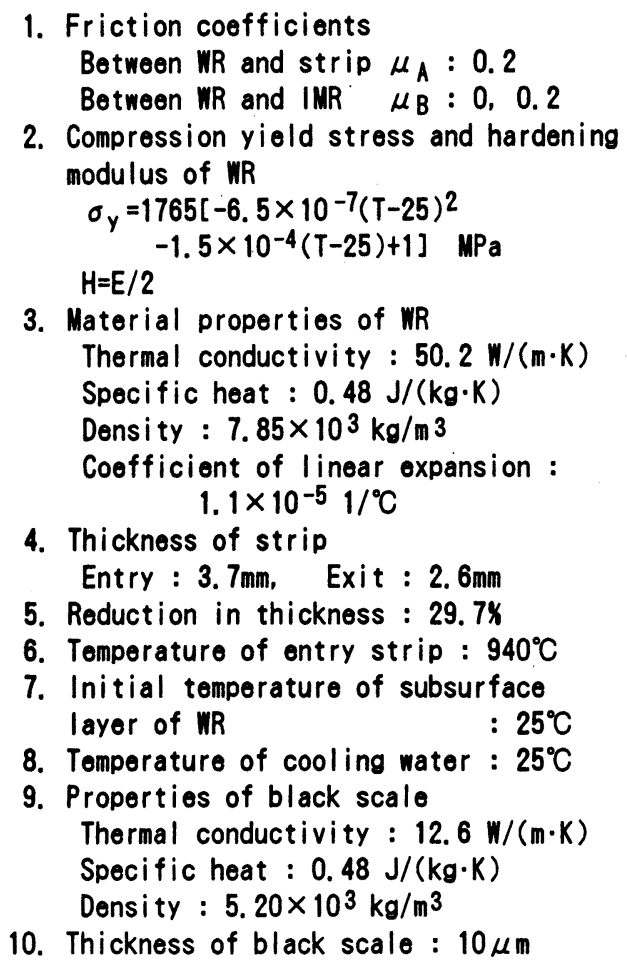

3. Material properties of WR

Thermal conductivity : $50.2 \mathrm{~W} /(\mathrm{m} \cdot \mathrm{K})$

Specific heat : $0.48 \mathrm{~J} /(\mathrm{kg} \cdot \mathrm{K})$

Density : $7.85 \times 10^{3} \mathrm{~kg} / \mathrm{m}^{3}$

Coefficient of linear expansion : 1. $1 \times 10^{-5} 1 /{ }^{\circ} \mathrm{C}$

4. Thickness of strip

Entry : $3.7 \mathrm{~mm}$, Exit : $2.6 \mathrm{~mm}$

5. Reduction in thickness : $29.7 x$

6. Temperature of entry strip : $940^{\circ} \mathrm{C}$

7. Initial temperature of subsurface layer of WR

8. Temperature of cooling water : $25^{\circ} \mathrm{C}$

9. Properties of black scale

Thermal conductivity : $12.6 \mathrm{~W} /(\mathrm{m} \cdot \mathrm{K})$

Specific heat : $0.48 \mathrm{~J} /(\mathrm{kg} \cdot \mathrm{K})$

Density : $5.20 \times 10^{3} \mathrm{~kg} / \mathrm{m}^{3}$

10. Thickness of black scale : $10 \mu \mathrm{m}$

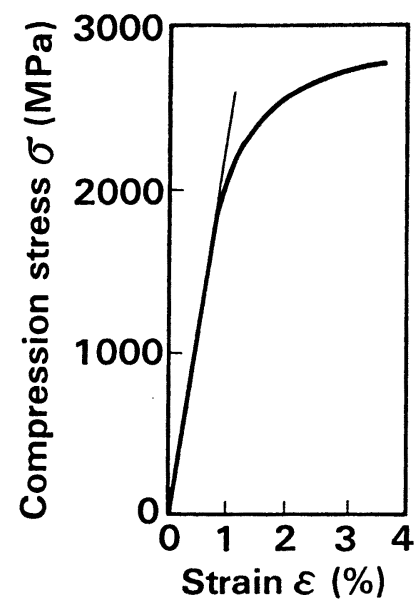

Fig. 6. Relation between compression stress and strain for rolling material.
高速度鋼の高温硬度特性 ${ }^{10)}$ を参考にして作成し, Table 2 の中に示す。また，この数值解析は熱間条件であるため， 圧延ロールと圧延材料の熱物性值等も Table 2 の中に示し ている。なお, WR と材料との間の摩擦係数 $\mu_{\mathrm{A}}$ は通常の熱延 を想定して 0.2 の值を用いるが，WRとIMRとの間の摩擦 係数 $\mu_{\mathrm{B}}$ は，通常の熱延の場合とWR表面上に激しい焼付き が発生した場合とを想定して，0 と 0.2 の值を用いる。

Fig.7 は, 今回の圧延条件を用い, 応力·熱負荷連成の熱

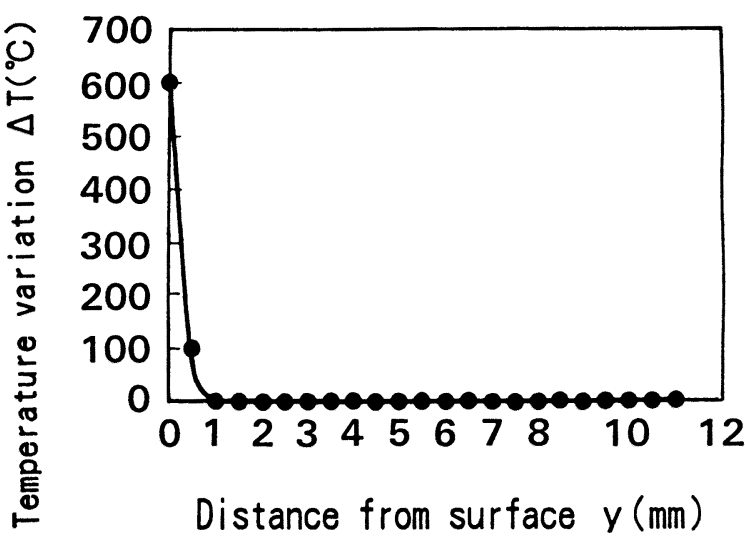

Fig. 7. Relation between temperature variation $\Delta \mathrm{T}$ and distance from surface of work roll $\mathrm{y}$.

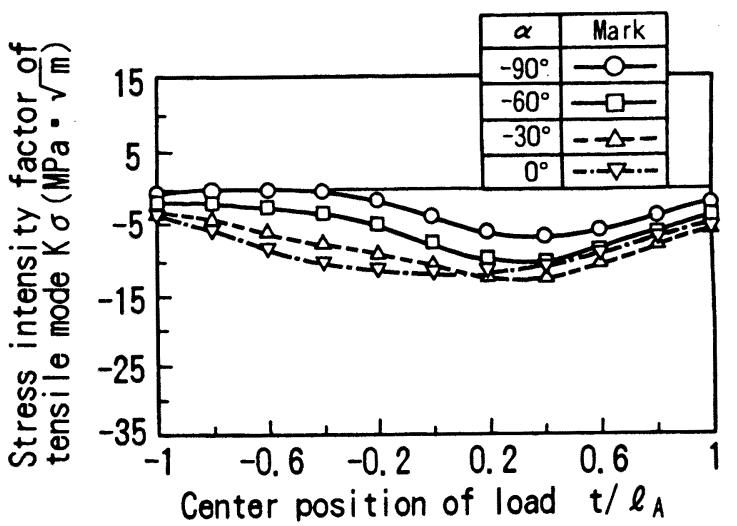

(a) Stress intensity factor of tensile mode $\mathrm{K} \sigma$

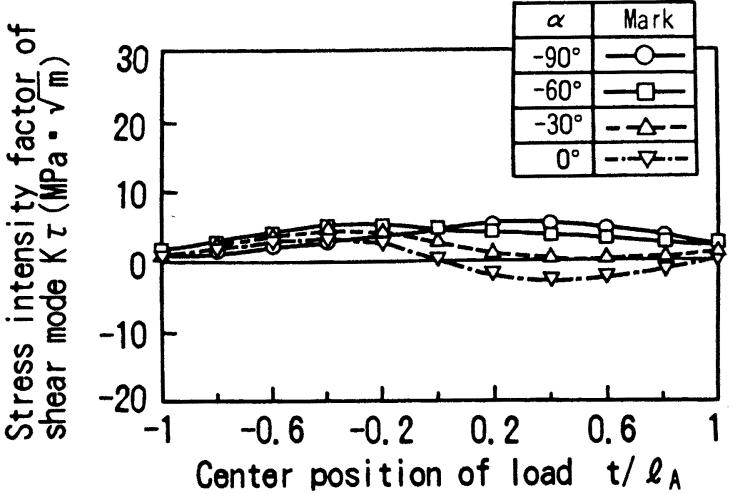

(b) Stress intensity factor of shear mode $K \tau$

Fig. 8. Effect of center position of load $t / \ell_{A}$ and angle $\alpha$ on stress intensity factors of tensile and shear modes on material (A) side $\left(\mu_{\mathrm{A}}=\right.$ $0.2, \beta=0^{\circ}, \ell_{\mathrm{A}}=9.95 \mathrm{~mm}$ ). 
弹塑性応力・歪数值解析モデル8)によって求めたWR表層の 温度変化とWR表面からの距離との関係である。この温度 変化は, Fig. 3 に示している圧延において,WRが圧延材料 と接触している間に発生し，接触が終わると,水冷却によっ て温度変化は 0 に戻る。このようなWRの温度变化のもと で，WR表層に存在する亀裂先端の応力拡大係数が計算さ れる。Fig. 8 は, 材料側 (A側)における引張型および剪断型 応力拡大係数 Kのおよび $\mathrm{K} \tau$ に及ぼす荷重分布の中心位置 角度 $\alpha=\theta+\beta$ (Fig. 1 参照) との影響である。引張型応力拡

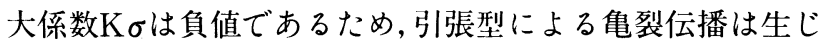
ないと推察される。また, IMR側(B側)における引張型およ

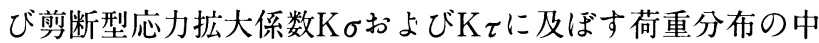
心位置 $と$ 角度 $\alpha$ の影響は, WR と IMR との間の摩擦係数 $\mu_{\mathrm{B}}$ が 0 の場合をFig. 9 に, $\mu_{\mathrm{B}}$ が 0.2 の場合をFig.10に示寸。 摩擦係数 $\mu_{\mathrm{B}}$ が大きくなると, 引張型応力拡大係数 $\mathrm{K} \sigma$ の最 大值(正値)はわずかに増加し, 剪断型応力拡大係数 $\mathrm{K} \tau$ の正 值側の最大值も増加するが，K $\mathrm{\tau}$ の負值側の最大值(最小值 の絶対値) は減少する。また，応力拡大係数の引張型 $\mathrm{K} \sigma$ の 最大值 (正值) $\varepsilon$ 剪断型 $\mathrm{K} \tau$ の最大值 (絶対值の最大値) $\varepsilon$ を

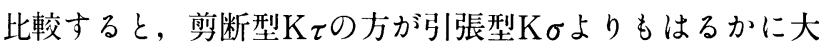
きいことが分かる。このことは, WR材料の亀裂伝播開始の 特性值である応力拡大係数の敷居值が引張型と剪断型でほ

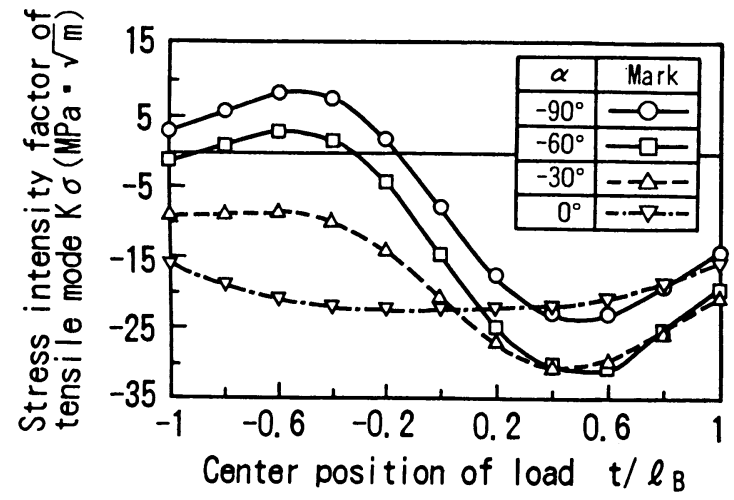

(a) Stress intensity factor of tensile mode $K \sigma$

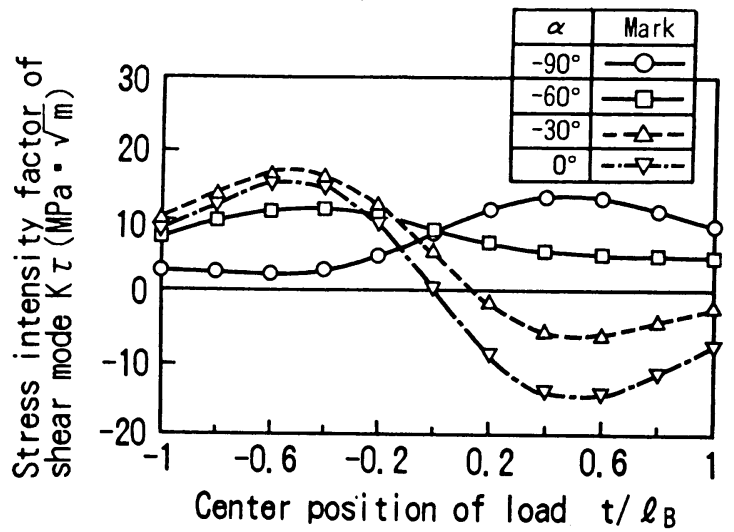

(b) Stress intensity factor of shear mode $K \tau$

Fig. 9. Effect of center position of load $t / \ell_{\mathrm{B}}$ and angle $\alpha$ on stress intensity factors of tensile and shear modes on IMR (B) side $\left(\mu_{\mathrm{B}}=0\right.$ $\beta=0^{\circ}, \ell_{\mathrm{B}}=2.18 \mathrm{~mm}$ ).
ぼ同じレベルであるならば，亀裂の伝播は剪断型で発生す ることを示唆する。この示唆は, 八イス系熱延WRの伝播亀 裂破面の観察結果 ${ }^{1)}$ と一致する。さらに, Fig. 8 と Fig. 9 お よびFig.10 とを比較すると,引張型および剪断型応力拡大 係数は，いずれも材料側 (A側)よりも IMR側 (B側)の方が 大きい。このことは，亀裂の伝播は材料側 ( $\mathrm{A}$ 側で発生する のではなく，IMR側(B側)で発生することを示唆する。

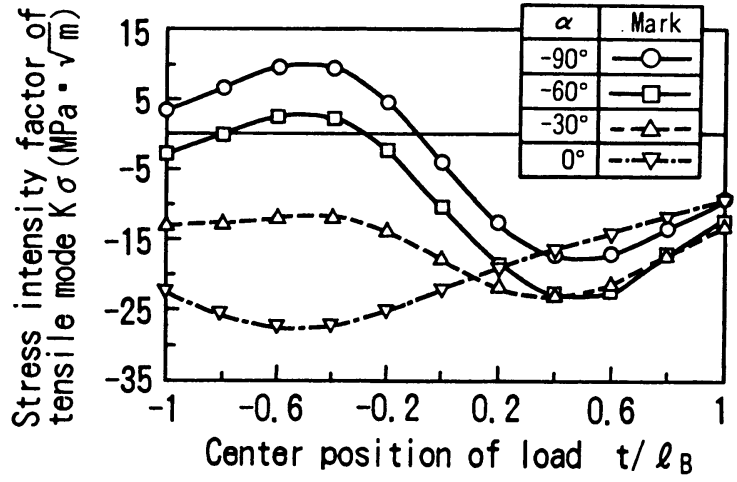

(a) Stress intensity factor of tensile mode $K \sigma$

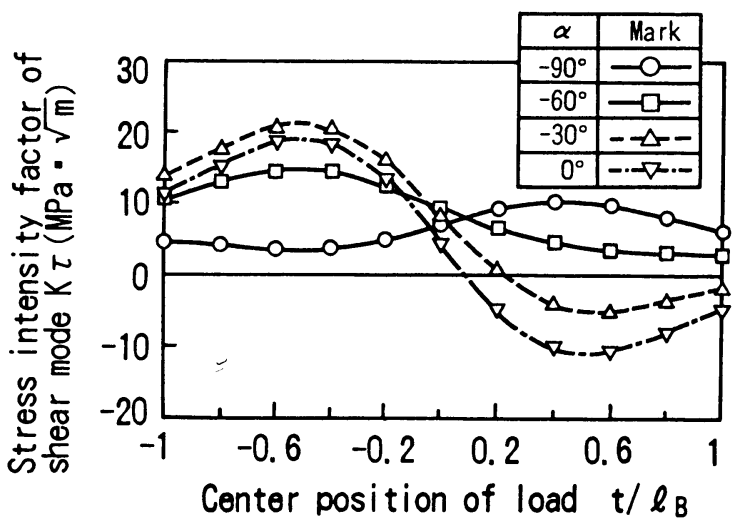

(b) Stress intensity factor of shear mode $K \tau$

Fig. 10. Effect of center position of load $t / \ell_{\mathrm{B}}$ and angle $\alpha$ on stress intensity factors of tensile and shear modes on IMR (B) side $\left(\mu_{\mathrm{B}}=0.2\right.$, $\left.\beta=0^{\circ}, \ell_{\mathrm{B}}=2.18 \mathrm{~mm}\right)$.

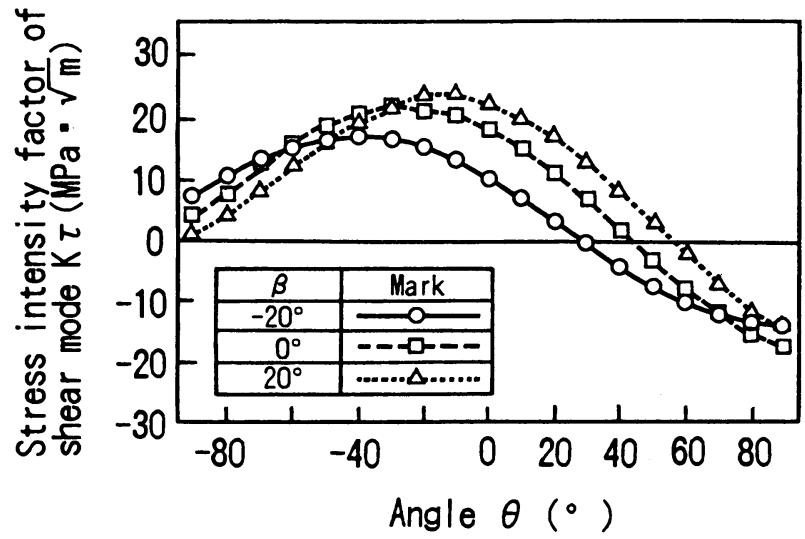

Fig. 11. Effect of angles $\theta$ and $\beta$ on stress intensity factors of shear mode on IMR (B) side $\left(\mu_{\mathrm{B}}=0.2, \mathrm{t} / \ell_{\mathrm{B}}=-0.6, \ell_{\mathrm{B}}=2.18 \mathrm{~mm}\right)$. 


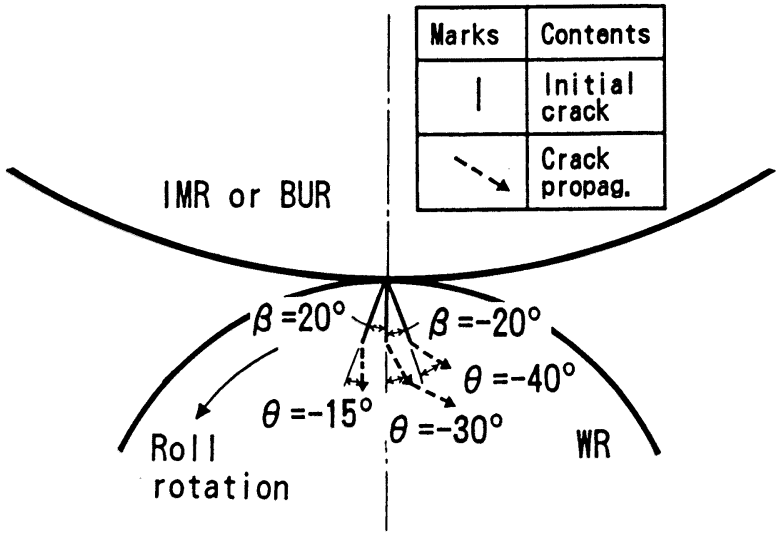

Fig. 12. Propagation direction of shear mode crack.

Fig.11 は, IMR側 (B側)の剪断型応力拡大係数 $\mathrm{K} \tau$ に及 ぼす亀裂角度 $\beta$ と角度 $\theta$ の影響である。Fig.11 から剪断型 亀裂の伝播方向を求めると, Fig.12が得られる。この結果 から，熱延WR表層に生じる熱亀裂のようなほぼWR表面 に垂直な初期亀裂を起点とする剪断型亀裂は，ロールの回 転方向と逆の方向に伝播し，伝播とともに次第にWR表面 に平行となるように進展することが推察される。このこと は, ハイス系熱延WRの剪断型亀裂の伝播方向の調査結果 ${ }^{11}$ と一致する。

以上のことを考慮すると，今回導いた圧延WRの表層龟 裂における応力拡大係数の数值解析モデルは，ハイス系熱 延WRの哂裂伝播の発生現象1を比較的良く説明できると 考えられる。

\section{5. 結言}

村上 $5^{5}$ が求めた無次元応力拡大係数を考慮して, 複合 モードの応力拡大係数の簡易モデルを導出した。そして， 既に報告している圧延ロール表層の応力・熱負荷連成の熱 弹塑性応力・歪数值解析モデル8)にこの簡易モデルを適用 して，圧延WRの表層亀裂における応力拡大係数の簡易数 值解析モデルを作成した。この簡易数值解析モデルを用い て，熱間圧延におけるWRの表層亀裂の応力拡大係数を計 算し，表層亀裂の伝播機構について検討した。以下に主要 な結果を要約する。

（1）今回導いた簡易数值解析モデル と，村上ら $5^{7}$ が体積 力法を用いて作成した複合モードの応力拡大係数の数值解 析モデルとを冷間 2 円筒接触の計算結果で比較すると, 両
モデルは応力拡大係数の極大と極小を示す位置が若干異 なっているが，両モデルの応力拡大係数の極大值と極小值 はほぼ一致する。圧延ロールのようなころがり・すべり問 題においては，荷重分布位置が円周上を移動するため，応 力拡大係数の極大と極小の位置は重要でなく，大きさが重 要であるため, 今回導いた応力拡大係数の簡易数值解析モ デルは十分適用できると考えられる。

(2) 今回の熱間圧延の計算条件では，材料側 (A側)にお いて, 引張型応力拡大係数が負值であるため, 引張型によ る亀裂伝播は生じないと推察される。

(3) 材料側 $\varepsilon$ IMR 側 (B側) の応力拡大係数を比較する と, 引張型および剪断型応力拡大係数は，いずれも材料側 よりもIMR側の方が大きい。このことは，亀裂の伝播は材 料側で発生するのではなく，IMR側で発生することを示 す。

（4）IMR側において, 応力拡大係数の引張型 $K \sigma$ の最大 值(正值) $飞$ 剪断型 $\mathrm{K} \tau$ の最大值(絶対值の最大值) $\varepsilon$ を比較

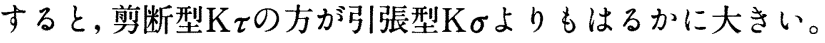
このことは, WR材料の亀裂伝播開始の特性值である応力 拡大係数の敷居值が引張型と剪断型でほぼ同じベルである ならば，亀裂の伝播は剪断型で発生することを示唆する。

（5）今回の数值解析から，ほぼWR表面に垂直な初期亀 裂を起点とする剪断型亀裂は，ロールの回転方向と逆の方 向に伝播し，伝播とともに次第にWR表面に平行となるよ うに進展することが推察される。

最後に, 応力拡大係数の数值計算プログラムの使用 $と$ 御 指導で大変お世話になった九州大学・工学部・機械工学科 村上敬宜教授および栄中講師に感謝の意を表します。

\section{文献}

1）松永栄入郎, 佐野義一, 野田 朗：材料とプロセス，8 (1995), 1266.

2）例えば，岡村弘之：線形破壊力学入門，培風館，(1976), 24.

3 ) J.C.Lee, T.N.Farris and L.M.Keer: Eng. Frac. Mech., 27 (1987), 27.

4) Y.Murakami : Eng. Frac. Mech., 22 (1985), 101

5 ）村上敬宜, 石田 誠：日本機械学会論文集A, 50-455 (1984), 1359.

6) F.Erdogan and G.C.Sih: J. Basic Engng., Trans. ASME, 85 (1963), 519.

7) Y.Murakami, M.Kaneta and H.Yatsuzuka: ASLE Trans., 28 $(1985), 60$.

8 ）山本普康，内田 秀，井上 剛，荒谷省一，中島浩衛：鉄 鋼， 82 (1996), 599 .

9 ) J.E.Merwin and K.L.Johnson: Proc. Inst. Mech. Eng., 177 (1963), 667.

10）日本金属学会編：金属便覧, 丸善 $(1960), 511$. 